\title{
Development of learning design based on realistic mathematics education
}

\author{
Fitriana ${ }^{1}$, Edwin Musdi ${ }^{2}$, and Azwir Anhar ${ }^{3}$ \\ ${ }^{123}$ Universitas Negeri Padang, Padang - Indonesia, (e-mail) fitriana.siigashu@gmail.com
}

\begin{abstract}
The aim of this research is to develop the learning design based on Realistic Mathematics Education and to develop reasoning skills. The research design combines the Plomp model and the Gravemeijer and Cobb model, that consist of preliminary research phase, prototype development phase, preparation for the experiment, the implementation of the experiment, retrospective analysis, and assessment phase. Data were collected through tests, interviews, observation, questionnaire and field notes. The subject of this research is VII grade student in Islamic junior high school 6 Piladang. The Learning design that was developed learning trajectory, that include learning objectives, activities, and prediction of students' answers implemented through the lesson plan and student worksheet. The result of this research produced a learning design which are valid, practical and effective. They are valid in terms of content and language, practical in terms of implementation, simplicity and required time. Effective in term of the impact of students' mathematical reasoning skills.
\end{abstract}

Keywords: learning design, realistic mathematics education, reasoning skills

\section{Introduction}

The main goal of mathematics learning in schools is that students have adequate mathematical skills to pursue higher education and to solve problems in everyday life. Such mathematical skills include problem solving, reasoning, communication, connection, and mathematical representation, as well as high level thinking skills, such as critical and creative thinking (Fauzan, 2013). Based on the results of PISA evaluation ( Program for International Students Assessment) and TIMSS ( Trends in Mathematics and Science Study) in 2015 shows that the reasoning skills of Indonesian students has not been optimally developed. For example, equation and linear inequality of one variable topics, the students have difficulty in solving the given problem, because on this topic relates to algebra that using variables ( Vaiyavutjamai : 2016). According to Herutomo (2014) the students usually make the mistakes about the concept of variables such as mistakes to understand the letters as a label, less understanding of the variable as something that has not known value and error in forming the equation.

Based on Observation at 5 April to 6 September 2017 in SMPN 1, SMPN 2 in sub districts Akabiluru and MTsN Piladang, indicate that students did not use their reasoning properly in solving the given problems. Teachers had attempted to apply instructional designs that 
could keep learners active in learning to develop their reasoning abilities, but the learning objectives had not been maximized and mathematical reasoning skills of the students still low.

This problem had a negative impact for the students, so that it's required learning design that was able to overcome the problemsof the students in learn-ing mathematics.

One of the real forms of learning design is the Lesson Plan (RPP). Ramadhanti (2015) states that "The lesson plan is better if it comes with predictions about how likely learners are learn. Accordances with Wijaya (2009), teachers should pro-vide alternative hypothesis, to help teachers cope with possible difficulties that faced by learners. Learning design based on learning path is known as Hypotetical Learning Trajectory (HLT). According to Simon (1995: 122), HLT consists of three components; the purpose for meaningful learning, a set of tasks to achieve goals, and hypotheses about how learners learn and how learners think, with HLT learning activities are more dynamic.

The development of instructional design that considers how students' thinking ability develops in learning activities according to Realitic Mathematic Education approach. Dutch scientists recognize that the learners who do mathematics with RME approachhas a higher score if compared with learners whose learning through traditional approach in terms of numeracy skills, more specifically in the application (Haryono, 2014: 105). Veloo (2015) states that RME supports students to become active learners . According to Turmudi (2014) generally learners are positive toward realistic based mathematics learn-ing. Based on Afriadi research (2017), concluded that application of learning path with RME approach can improve the mathematical reasoning abilities of learners, which accordances with the research of Fauzan (2002), Rangkuti (2015), and Arisca (2017).

The three main principles of RME according to Gravemeijer (1994) (1) guided reinventation and progessive mathematizing (2) didactical phenomenology and (3) self-developed models. The principles of RME according to Freudenthal (in Gravemeijer, 1994) isoperationalized into five basic characteristics, that are: (a) The use of contexts(b) The use of models, bridging by vertical Instrumens (c) The use of student contribution (d) Interactivity and (e) the intertwining.

Freudenthal (1991) argues that mathematics must be related to reality, the problems that given to the learner should be relevant to the life of society, and the material must be transmitted as human activities. Sothat, the learners can develop the skills of mathematical reasoning through the guidance of teachers to rediscover mathematical formulas or concepts. Based on the background is believed RME based learning design can help learners to develop the skills of mathematical reasoning. The aim of this research is to develop the learning design based on Realistic Mathematics Education of $\mathrm{c}$ and to develop reasoning skills which meet the valid, practical, and effective criteria.

\section{Methods}

This research is a design research that combines the model of Plomp (2013) and model Gravemeijer and Cobb (2006). The learning path was developed using Gravemeijer and Cobb model through three phases, preparing for the experiement phase, conducting experiment and analysis restrospective. Furthermore, to develop the product from the learning design in the the lesson plan and student worksheet by using Plomp model.

The three phases of the Plomp model are (1) the preliminary research phase, that consist of needs analysis, curriculum analysis, learner analysis, concept analysis and literature review. Initial investigation is a basis for determining alternative solutions and specifications of required product and identifying materials that suitable for the implementation of learning design based on Realistic Mathematics Education. (2) Phaseprototyping stage, a prototype that had been designed 
then assessed through formative evaluation. Learning design based on Realistic Mathematics Education that had been designed by it self evaluated and validated by expert review. If learning design based on Realistic Mathematics Education considered valid, further one to one evaluation, small group evaluation, and field tests. (3) Assessment phase, which is the assessment of mathematical reasoning skills of the students to see the effectiveness of learning devices that developed.

The field test of instructional design conducted on 7th grade students of MTsN 6 Piladang. The data were collected through tests, interviews, observations, questionnaires and field notes. The data from the research are then analyzed, the techniques of data analysis that used are descriptive statistics and descriptive techniques. Descriptive statistics to analyze students' learning outcomes, observation sheets, and questionnaires. While the descriptive technique to analyze the results of interviews and field notes.

\section{Results and Discussion}

This study begins with preparing for the experiment. The preparatory stage aims to formulate an alleged learning path that can be expanded/ elaborated and improved upon implementation of the experimental design (Gravemeijer and Cobb, Based on needs analysis, curriculum analysis, concept analysis, learner analysis, and literature review, the learning design based on Realistic Mathematics Education about one variable linear equation and inequality for 7th grade students in the form of Hyphotetical Learning Trajectory (HLT). HLT that was designed consists of 3 parts, that are learning objectives, a set of activities to gain goals and hypotheses about how learners learn and think (Simon, 1995). In addition to predictions the answer, it is necessary to prepare anticipation in the form of questions that will beasked by teachers to guide learners achieve learning objectives that have been set. HLT presents activities with a context that close to the learner in the following order:

Form a linear equation of one variable by human activities

Figure 1. Flow Chart about Equation And Linear Inequality Of One Variable

The designed HLT is implemented in the form of RPP (lesson plan) and LKPD (student's worksheet). RPP as teacher guidance in implementing learning in the class room. The component of RPP is designed based on Permendikbud No. 22 of 2016 on process standards for basic and middle educational units. RPP based on the characteristics and principles of RME too. Furthermore LKPD as guidelines for the learners in learning.LKPD contains contextual problems in the form of learning activities and exercises to be completed by the learner. 
The products that have been designed, has been trough formative evaluation that developed to assess the quality of developed product. The average value of overall HLT validity is 3.6 so it is concluded that the aspect of the RME-based HLT component is valid as follows:

Table 1. Results of HLT Validation

\begin{tabular}{crcc}
\hline No & Aspect & Average & Category \\
1 & Contents & 3.6 & Very Valid \\
2 & Language & 3.6 & Very Valid \\
& Average overall & 3.6 & Very Valid \\
\hline
\end{tabular}

Sources: The research reports, 2018

Table 2. Results of RPP Validation

\begin{tabular}{llcl}
\hline No & \multicolumn{1}{c}{ Aspect } & Average & Category \\
1 & RPP Components & 3.7 & Very Valid \\
2 & Learning Activities & 3.6 & Very Valid \\
3 & Language & 3.7 & Very Valid \\
& Average overall & 3.7 & Very Valid \\
\hline
\end{tabular}

Sources: The research reports, 2018

RPP validation results are declared valid as shown in Table 2. The result of validation of LKPD that used by the learners obtain validity value of 3.6 which is categorized as very valid and LKPD can be used by learners as illustrated in Table 3 .

Table 3. Results of LKPD Validation

\begin{tabular}{llcl}
\hline No & \multicolumn{1}{c}{ Aspect } & Average & Category \\
1 & Presentation & 3.6 & Very Valid \\
2 & Feasibility of Content & 3.6 & Very Valid \\
3 & Language & 3.6 & Very Valid \\
4 & View & 3.5 & Very Valid \\
& Average overall & 3.6 & Very Valid \\
\hline
\end{tabular}

Sources: The research reports, 2018

At the Conducting The Experiment stage, after all the products that developed are valid, then the test activities of learning path are conducted. The activity aims to test and improve the alleged learning path and see the practicality of the learning flow that has been designed. Activity begins with one-to-one evaluation . Retrospective analysis of one to one evaluation is about the changes of context used from thecontext about weighing brown sugar into the context of the Feast of Allowance, since the problem with the context of weighing brown sugar can make learners confused and have many perceptions. The activities to form inequality need additional questions that guide learners to construct their knowledgeandsome activities require additional anticipation so that learners can achieve learning objec-tives.Furthermore there are typing errors, and improvements to the inaccurateLKPD answer sheet for writing learners' answers .

After the revision of one to one results evaluation, then conducted small group evaluation, which was the first conducting experiment cycle on the development of the Gravemeijer \& Cobb model. Results of retrospective analysis on small group evaluation that the first meeting was initially formed one variables linear equations and inequality that put together consisting of six activities, but the available time is very fitting, so that this one meeting split into two meetings. At first meeting, forms a linear equation of one variable and encounter 2 , forms a linear inequality of one variable. So that learners can achieve learning objectives optimally.

Large group testing is also called second cycle conducting experiment on developing model of Gravemeijer \& Cobb. Large group tests were conducted in class VII.2 that consisting of 31 students. Learning activities are conducted in groups, for 6 meetings.Problems are given using a context that 
close to the learner. Resolve the contextual problems make students use their reasoning skill, so that their reasoning skills will increase. If students experience difficulties then the teacher as a facilitator, guide the learners by asking questions so that learners can achieve the expected learning objectives. Prediction and anticipation of learners' answers have been prepared in RPP as a guide for teachers to create more dynamic learning activities.

Learning design based on RME provides an opportunity for learners to solve problemsin their own way in accordance with the mindset of learners developing. For example, in the activity of finding the concept of solving linear equations of one variable with the context of Hari Raya allowance, following are example of the learner's answer.

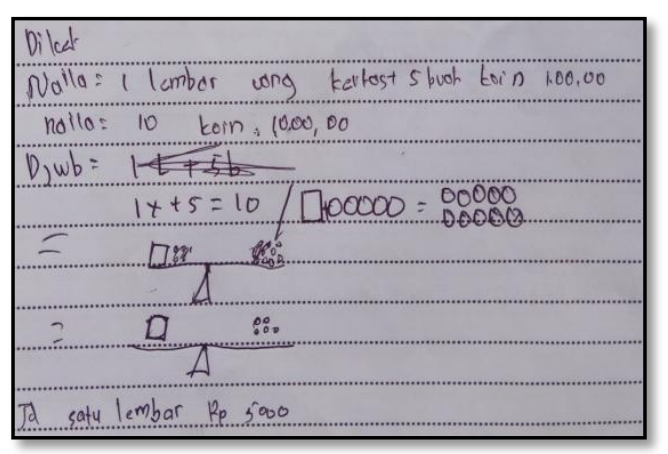

(a) Student's Answer

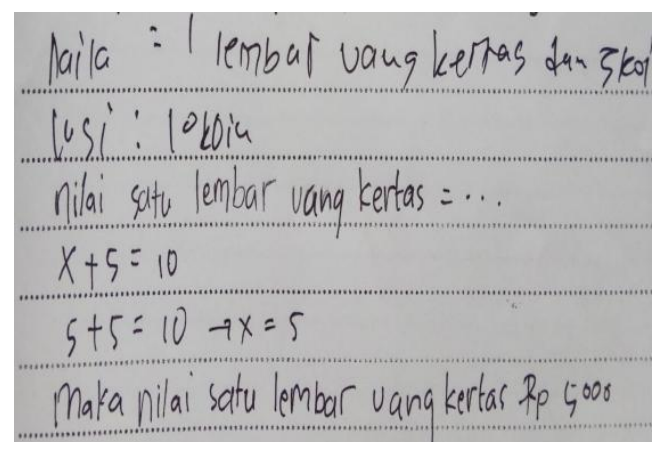

(c) Student's Answer

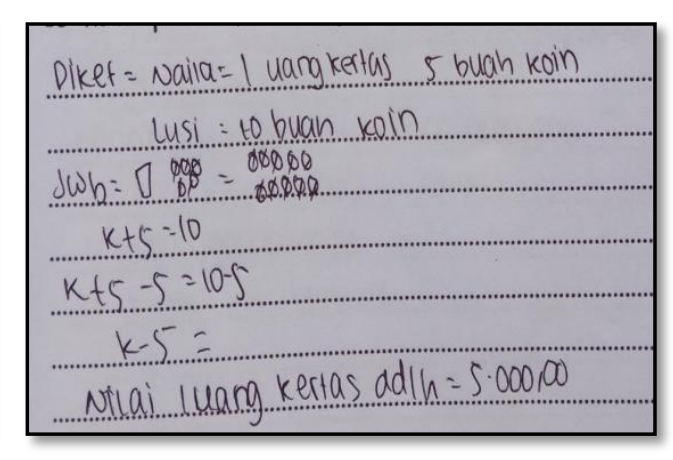

(b) Student's Answer

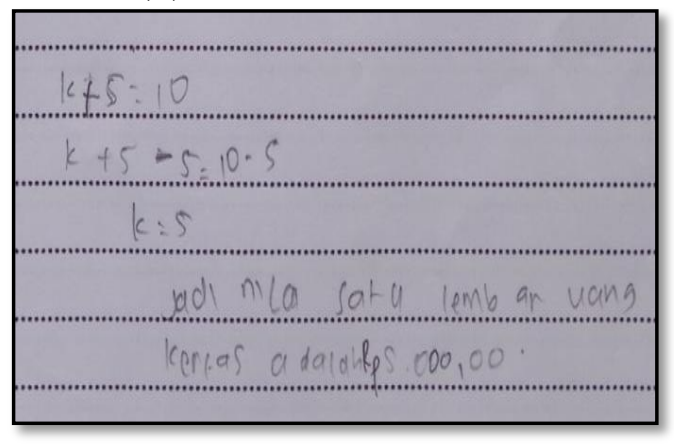

(d) Student's Answer

Figure 2. Example Student's Answer of Activity 5.1 on the Field Test

Sources: The research reports, 2018

Figure 2 shows that the learner understands the given problem and solves it according to their understanding. In the answers (a) and (b) learners use the help of drawings, (c) learners try to substitute the value of $x$, then conclude the answer based on the substituted value. In the answer sheet $(\mathrm{d})$ learners solve the problem by using the properties of linear equations of one variable. Then teacher asks the student's representatives to write the answers according to the way they find and discuss it. Furthermore, teachers together with learners make agreement on the answers used to solve equations, so that learners more easily solve the next given problem.

The results of interviews, teachers said the design of the RME-based learningcreates the interaction between learners and learners with teachers.The class discussionthat discusses variousstrategies were found by learners make them aware of various ways to find solutions and find out the right answer. Learners are more active in learning so that the role of teacher as a facilitator onlyprovide guidance if learners have difficulty in learning. 
Based on the results of interviews with students, concluded that learning design based on RME that developed can rise a positive attitude on the learners. Learners weredelighted to learn mathematics, learners are more daring to ask and convey its ideas to contribute in learning. In addition, learners are challenged to solve the given problems because the problem uses a context that closeto everyday life .

Practicalities questionnaires given to teachers and learners after completion of the learning process to determine the practicality level of instructional design that developed. The percentage result of teacher practice questionnaire is $92 \%$ and the percentage of questionnaire practicity by learners is $84 \%$, it's mean learning design based on RME is considered practical .

The result of the mathematical reasoning test of the learner after field test as follows.

Table 4 . The Value of Mathematical Reasoning Ability

\begin{tabular}{clcc}
\hline No & \multicolumn{1}{c}{ Reasoning Indicator } & $\begin{array}{c}\text { Percentage } \\
1\end{array}$ & $\begin{array}{c}\text { Category } \\
\text { Very good }\end{array}$ \\
2 & $\begin{array}{l}\text { Observe the pattern or regularity to make } \\
\text { Provide explanations using facts and their } \\
\text { properties. }\end{array}$ & $73 \%$ & Good \\
3 & $\begin{array}{l}\text { Doing math manipulation. } \\
\text { Construct or assess mathematical conjecture / } \\
\text { argument. } \\
\text { Illustrates the logical conclusion of a number of } \\
\text { ideas and their interrelationships. } \\
\text { Average Percentage (\%) }\end{array}$ & $63 \%$ & Very good \\
& $66 \%$ & Very good \\
\hline
\end{tabular}

Sources: The research reports, 2018

Based on the data on the table can be seen the average percentage for all reasoning indicator obtained $83 \%$ which catagorized as very good. When viewed from the percentage of the number of learners, $42 \%$ of students have good reasoning mathematical reasoning ability and $58 \%$ with very good category as in Figure 2.

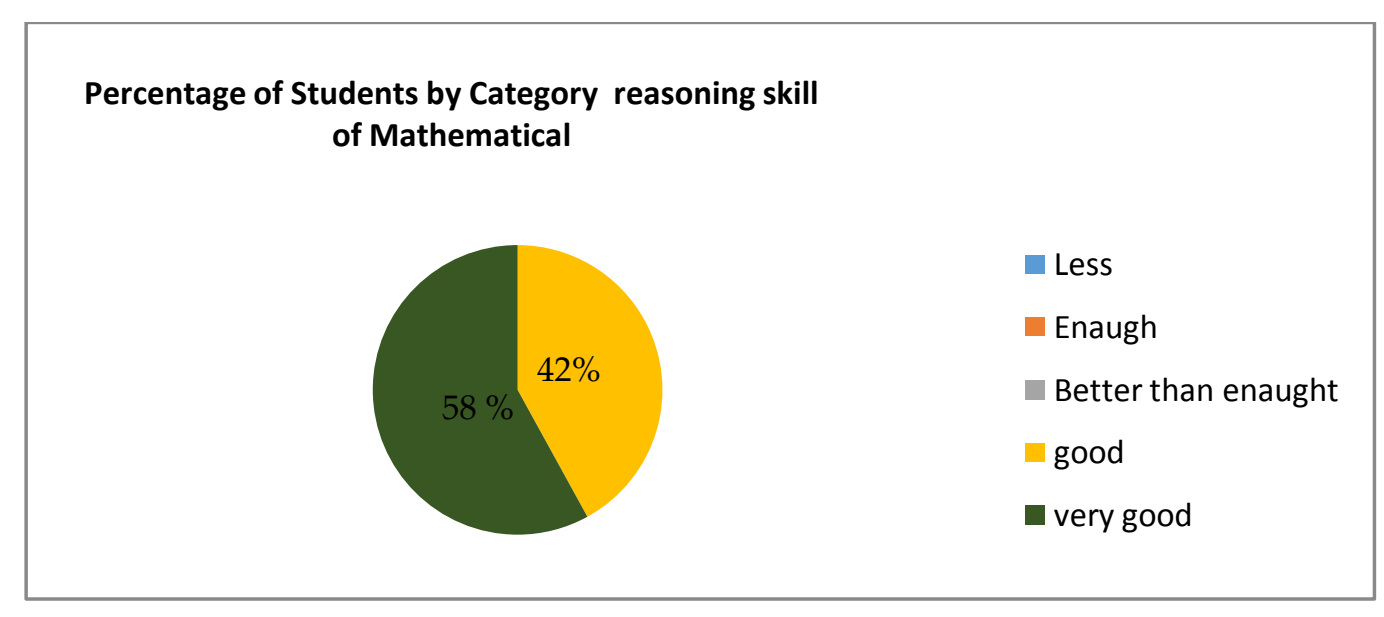

Figure 2. Perentage of Students by reasoning skill of Mathematical Mathematical. 
Furthermore, $81 \%$ of the total number of learners get score above 75 . This indicates that the questions given are understandable to learners and illustrate that the learning design based on RME can embed the basic concepts of the topic of equation and linear inequality of one variable to learners. It can be said that the instructional design that was developedincluding in effective category.

\section{Conclusions}

Based on the results of research and data analysis, it is concluded that the learning design based on RME in the equation and inequality linear of one variabel has been valid, practical and effective. Valid in terms of content and language. Practical in terms of implementation, ease and time required. Effective in terms of the impact of students' mathematical reasoning skills. So RME-based learning design about one variable linear equations and inequality can be used as a guide for teachers in implementing learning to improve students' mathematical reasoning skills.

\section{Acknowledgments}

Appreciation and thanks the author gave to:

1. Dr. Edwin Musdi, M.Pd and Dr. Azwir Anhar, M.si as mentors in this research.

2. Prof. Dr. Ahmad Fauzan, M.Pd, M.Sc., Bapak Dr.Irwan, M.Si., and Dr.Hardeli, M.Si, as a contributor.

3. Dr. Dony Permana, M.Si, Dr. Ali Asmar, M.Pd, dan Mulyadi, M. Pd as validator instrument of research.

4. Prof.Dr. Ahmad Fauzan, M. Pd, M.Sc, Drs. Hendra Syarifuddin, M.Si., P.hD, Dr. Dony Permana, M.Si, Mulyadi, M. Pd, and Dr. Jasrial, M.Pd as validator of learning design.

5. Prof.Dr. Ahmad Fauzan, M. Pd, M.Sc, Dr. Yerizon, M.Si, dan Dr. Dony Permana, M.Si as validator of reasoning ability test.

6. Drs.H.Yusrial, Kurniati, S.TP, S.Pd, Alisa Rusda, S.Pd and students of MTsN 6 Piladang.

7. Eri Satria, S.Pd, Yessi Sylvia, S.Pd, and students of SMPN 1 Akabiluru.

8. Siswanto, S.Pd, Restu Dini, S.Pd and students of SMPN 2 Akabiluru.

9. Beloved family who always give prayers, passion, motivation and support morally and materially for the success of this research.

10. All parties who have assisted this research.

\section{References}

Afriadi, Juli. (2017). “ Pengembangan Desain Pembelajaran Topik Statistika Berbasis Realistic Mathematics Education (RME) Di Kelas IX SMP/MTs". Tesis tidak diterbitkan . Program Pascasarjana Universitas Negeri Padang.

Arisca ,Yona. (2017). "Pengembangan Desain Pembelajaran Bangun Ruang Sisi Datar Berbasis Realistic Mathematics Education (RME) untuk Meningkatkan Kemampuan Penalaran Siswa Kelas VIII SMP/MTs". Tesis. Program Pascasarjana Universitas Negeri Padang.

Biro Komunikasi dan Layanan Masyarakat Kementerian Pendidikan dan Kebudayaan. (2016). Peringkat dan Capaian PISA Indonesia Mengalami Peningkatan. Jakarta : Kementrian Pendidikan dan Kebudayaan RI. 
Fauzan, A dan Yerizon. (2013). Pengaruh Pendekatan RME dan Kemandirian Belajar Terhadap Kemamampuan Matematis Siswa. (Online). (Prosiding Semirata FMIPA Universitas Lampun. diakses 21 Agustus 2017)

Fauzan, Ahmad. (2002). Applying Realistic Mathematics Education (RME) in Teaching Geometry i Indonesian Primary Schools. Doctoral Dissertation. Enschede: University of Twente

Freudenthal, H. (1991). Revisting Mathematics Education. Dordrecht: KluwerAcademic Publisher.

Gravemeijer, K. (1994). Developing Realistic Mathematics Education. Utrecht: Freudenthal Institute.

Gravemeijer, Koeno and Cobb, Paul. (2006). Design research from the Learning Design Perspective. Dalam Jan Ven Den Akker, et. al. Educational Design Research. London: Routledge.

Gravemeijer and Cobb. (2013). Design Research from the Learning Design Perspective. In T. Plomp and N. Nieveen (Eds.), Educational Design Research-Part A: Introduction. Enschede, the Netherlands: SLO.

Haryono, Didi. (2014). "Filsafat Matematika". Penerbit. Alfabeta CV. Bandung.

Herutomo, Rezky Agung, Saputro, dan Tri Edi Mulyono. (2014). Analisis kesalahan dan miskonsepsi siswa kelas viii Pada materi aljabar. Edusentris, Jurnal Ilmu Pendidikan dan Pengajaran, Vol. 1 No. 2.(Online). Akses 26 September 2017.

Kemdikbud. (2016). Peraturan Menteri Pendidikan dan Kebudayaan Nomor 22 tahun 2016 tentang Standar Proses Pendidikan Dasar dan Menengah. Jakarta: Kemdikbud.

Plomp, T. (2013). Educational Design Research: an Introduction. Dalam Tjeerd Plomp dan Nienke Nieveen (Ed.). An Introduction to Educational Design Research. Enschede: SLO•Netherlands Institute for Curriculum Development

Ramadhanti. Putri. (2015). PenggunaanHypothetical Learning Trajectory (HLT) pada Materi Elastisitas Untuk Mengetahui Lintasan Belajar Siswa Kelas X di SMA Negeri 1 Indralaya Utara. Jurnal Inovasi dan Pembelajaran Fisika, Volume 2, Nomor 1, Mei 2015.

Rangkuti, Ahmad Nizar. (2015). Pengembangan Alur Belajar Topik Pecahan di Sekolah Dasar dengan pendekatan PMRI. Padang: Program Pascasarjana.

Simon, Martin A. (1995). Reconstructing Mathematics Pedagogy from a Conswtructive Perspective. Journal of Research in Mathematics Education. (Vol. 26. No.2. 135-137. Diakses pada tanggal 20 April 2016).

Turmudi, dkk. (2014). Pengembangan Pembelajaran Matematika Dengan Pemodelan (Mathematical Modeling) Berbasis Realistik Untuk Mahasiswa. Jurnal Pengajaran MIPA, Volume 19, Nomor 1, hlm. 1-18. DOI:10.18269/jpmipa.v19i1.419 .Akses 26 September 2017.

Vaiyavutjamai, Pongchawee and Clements, M. A .(2006). Effects of Classroom Instruction on Students'Understanding of Quadratic Equations. Mathematics Education Research Journal, Vol. 18, No. 1, 47-77. (Online). Akses 26 September 2017.

Veloo, Arsaythamby dkk. (2015). Effect of Realistic Mathematics Education Approach Among Pubic Secondary School Students In Riau, Indonesia. Australian Journal of Basic and Applied Sciences. ISSN:1991-8178

Wijaya, Ariyadi. (2008). Design Research in Mathematics Education Indonesian Traditional Games as Preliminaries in Learning Measurement of Length. Dalam Zulkardi (editor) Prosiding Konferensi Nasional Matematika XIV. Program Studi Magister Pendidikan Matematika. Program Pascasarjana Universitas Sriwijaya. 2008. 